\title{
Behavioural interactions between the endangered native fish Saramugo, Anaecypris hispanica, and the invasive Bleak, Alburnus alburnus
}

\author{
Janine da Silva ${ }^{1}$, Paula Matono ${ }^{1,2}$, Eduardo N. Barata ${ }^{3}$, João M. Bernardo ${ }^{1}$, Ana M. Costa ${ }^{1}$ and \\ Maria Ilhéu ${ }^{1,2, *}$
}

${ }^{1}$ Departamento de Paisagem, Ambiente e Ordenamento, Escola de Ciências e Tecnologia, Universidade de Évora, Colégio Luís António Verney, Rua Romão Ramalho 59, 7000-671 Évora, Portugal.

2 ICAAM, Instituto de Ciências Agrárias e Ambientais Mediterrânicas, Universidade de Évora, Núcleo da Mitra, Apartado 94, 7006-554, Évora, Portugal.

3 Departamento de Biologia, Universidade de Évora, Pólo da Mitra, Apartado 94, Évora, Portugal.

* Corresponding author: milheu@uevora.pt

Received: 31/12/17 Accepted: 22/05/18

\begin{abstract}
Behavioural interactions between the endangered native fish Saramugo, Anaecypris hispanica, and the invasive Bleak, Alburnus alburnus

Invasive species have the potential to impact native fish through interference competition, which is especially concerning for the conservation of the valuable endemic ichtyofauna of the Iberian Peninsula. This study investigated the potential negative effect of the invasive bleak Alburnus alburnus on the behaviour of the critically endangered Iberian saramugo Anaecypris hispanica. The behaviour patterns were analysed under experimental conditions in outdoor tanks through observations on shelter use, shoaling, space use, swimming and direct interactions between individuals. Saramugo showed a strong social character, being the monospecific shoal a sharp behavioural feature, independently on the presence of the bleak. Sheltering was also an important and consistent behaviour to the species. The presence of the bleak resulted in the increase of individual space exploration, as well as swimming and especially fast swimming events, and a wider use of the available space, including the water column in addition to the bottom. This points to higher activity levels of saramugo in the presence of the bleak. Negative direct interactions, particularly through aggression, were not frequent but only occurred when the bleak was present and were always triggered by this species. The future possible coexistence of these two species in the wild is likely to promote an increase of saramugo individual's activity, reducing shelter use and leading to higher metabolic expenses as well as predation risk.
\end{abstract}

Key words: Behavioural interactions, Anaecypris hispanica, Alburnus alburnus, invasive species, fish conservation, Guadiana river basin

\section{RESUMEN}

Interacciones comportamentales entre la nativa en peligro jarabugo, Anaecypris hispanica, y el invasor alburno, Alburnus alburnus

Los peces invasores pueden afectar a las especies nativas a través de la competencia por interferencia, representando un gran problema para la conservación de la ictiofauna endémica de la Península Ibérica. En este estudio se investigaron los posibles impactos del alburno Alburnus alburnus, especie invasora, sobre el comportamiento de una especie nativa en peligro crítico, el jarabugo Anaecypris hispanica. Los patrones de comportamiento fueron estudiados en condiciones experimentales en tanques al aire libre, a través de observaciones del uso de refugio, agrupamiento de individuos, uso del espacio e interacciones natatorias y directas entre individuos. El jarabugo mostró un carácter social muy fuerte, agrupándose en cardúmenes monoespecificos independientemente de la presencia del alburno. La especie mostró también una consistente tendencia al uso de refugios. La presencia del alburno produjo un aumento en la actividad de natación del jarabugo, especialmente en relación a movimientos rápidos, y un más amplio uso del espacio, incluyendo la columna de agua además del fondo. Esto apunta que el 
jarabugo aumenta su nivel de actividad en presencia del alburno. Finalmente, las interacciones negativas directas, como las agresiones, fueron poco frecuentes, pero ocurrieron únicamente cuando el alburno estuvo presente y siempre fueron desencadenadas por esta especie. Por lo tanto, la probable de coexistencia de estas dos especies en la naturaleza en un futuro podrá conllevar un aumento en la actividad del jarabugo, reduciendo el uso de refugios. Estos cambios comportamentales implicarían mayores gastos metabólicos y el aumento del riesgo de depredación, representando una amenaza potencial sobre esta especie en peligro.

Palabras clave: Interacciones de comportamiento, Anaecypris hispanica, Alburnus alburnus, especies invasoras, conservación de peces, cuenca del río Guadiana

\section{INTRODUCTION}

Rivers are among the most vulnerable ecosystems in the world, primarily affected by habitat loss and biological invasions (García-Berthou et al., 2005; Hermoso et al., 2011). Particularly in the Mediterranean region, these ecosystems are severely invaded by non-native species, fact that is especially alarming in the Iberian Peninsula, considered a biodiversity hotspot due to a high number of endemic fish (Leunda, 2010; Hermoso et al., 2011; Ilhéu et al., 2014).

Invasive fish species may cause alterations in the habitat conditions and ecosystems processes or directly reduce native populations and ultimately be responsible for local extinctions (Keller \& Brown, 2008; Van Kessel et al., 2011; Almeida \& Grossman, 2012). The knowledge on the specific mechanisms by which native fauna is displaced is still poor, though it has been linked to interference and exploitative competition, predation, disease introduction and hybridization (Leunda, 2010; Ribeiro \& Leunda, 2012).

The bleak, Alburnus alburnus (Linnaeus, 1758), is one of the most recently introduced species in the Iberian Peninsula and has experienced considerable increases in population abundance in the last decades (Vinyoles et al., 2007), particularly in the Guadiana basin (Ilhéu et al., 2014). This species is already known to have displaced endemic fish in Spain, namely the Ebro nase, Parachondrostoma miegii (Steindachner, 1866) (Almeida \& Grossman, 2012). Moreover, direct observations in the laboratory showed that the bleak significantly changes the Ebro nase behavioural patterns (Vinyoles et al., 2009; Almeida \& Grossman, 2012). Its strong invasive character makes it a common species composing the fish assemblages in the Guadiana basin, which may threaten the endemic fish fauna, especially the most vulnerable species, such as the critically endangered saramugo, Anaecypris hispanica (Steindachner, 1866). Saramugo is a small endemic Iberian cyprinid strictly confined to the Guadiana (Collares-Pereira et al., 1999) and Guadalquivir (De Miguel et al., 2010; Doadrio et al., 2011) basins and one of the most threatened freshwater fish in Portugal (Alves et al., 2001). Its abundance has declined dramatically over the past thirty years and this seems to be related to the expansion of exotic species and habitat disturbance (Collares-Pereira et al., 1999; Blanco-Garrido et al., 2009; Carrapato \& Ribeiro, 2012).

When native and non-native species display similar ecological traits and life histories, the risk of developing complex interactions increases (Schumann et al., 2015). Without an evolutionary history in coexistence, promoting ecological niche segregation, interactions between saramugo and bleak are likely to be expected as they also share a close phylogenetic relationship (ICN, 2005; Sousa-Santos et al., 2018). Even though these two species do not presently live in sympatry, there is evidence of a high ecological niche overlap between them (Ilhéu et al., 2016).

Behavioural shifts from sympatry with invasive species may very often represent the first responses to the biota alteration (Wong \& Candolin, 2015). The effects of invasive species on native fish communities have been relatively well documented, even though these are mostly addressed through indirect methods (e.g. dietary overlap, habitat use) that are not able to identify the specific mechanisms responsible for niche shifts (Almeida \& Grossman, 2012). Direct observations of fish behavioural interference 
have been poorly addressed (Van Kessel et al., 2011; Kakareko et al., 2013; Grabowska et al., 2016). In the Iberian Peninsula, most of these few studies concern interactions of native cyprinodontiform species with mosquitofish, Gambusia holbrooki (Girard, 1859) (Rincón et al., 2002; Caiola \& De Sostoa, 2005) and other non-cyprinid fish (Leunda, 2010). Nevertheless, the observed segregation and opposed population trends between the saramugo and the pumpkinseed sunfish, Lepomis gibbosus (Linnaeus, 1858) is suggested as a consequence of behavioural interference (Blanco-Garrido et al., 2009).

Aggression seems to be a main driver of species exclusion, resulting from the dominance of the invasive species upon the native ones (Blanco-Garrido et al., 2009; Leunda, 2010; Almeida et al., 2014). However, the specific mechanisms underlying the impact of non-lethal antagonistic interactions remain only partly understood. Some of these mechanisms can be related to indirect competition for space and food, changes in feeding behaviour (prey preference or feeding rate) and activity (Keller \& Brown, 2008, Schumann et al., 2015) but need to be addressed at the species-specific case level. Iberian cyprinids' behavioural interactions with invasive species have not been properly addressed. To the authors' best knowledge, only one study was performed by Vinyoles et al. (2009), regarding the effects of the bleak on the Ebro nase behavioural patterns (Almeida \& Grossman, 2012).

This study aimed to analyse the potential negative effects of the bleak upon the saramugo based on behavioural interactions under experimental conditions. Specifically, we intended to evaluate: i) the effects of the bleak on the behavioural patterns and activity of the saramugo; ii) the occurrence of aggressive and non-aggressive direct interactions between bleak and saramugo.
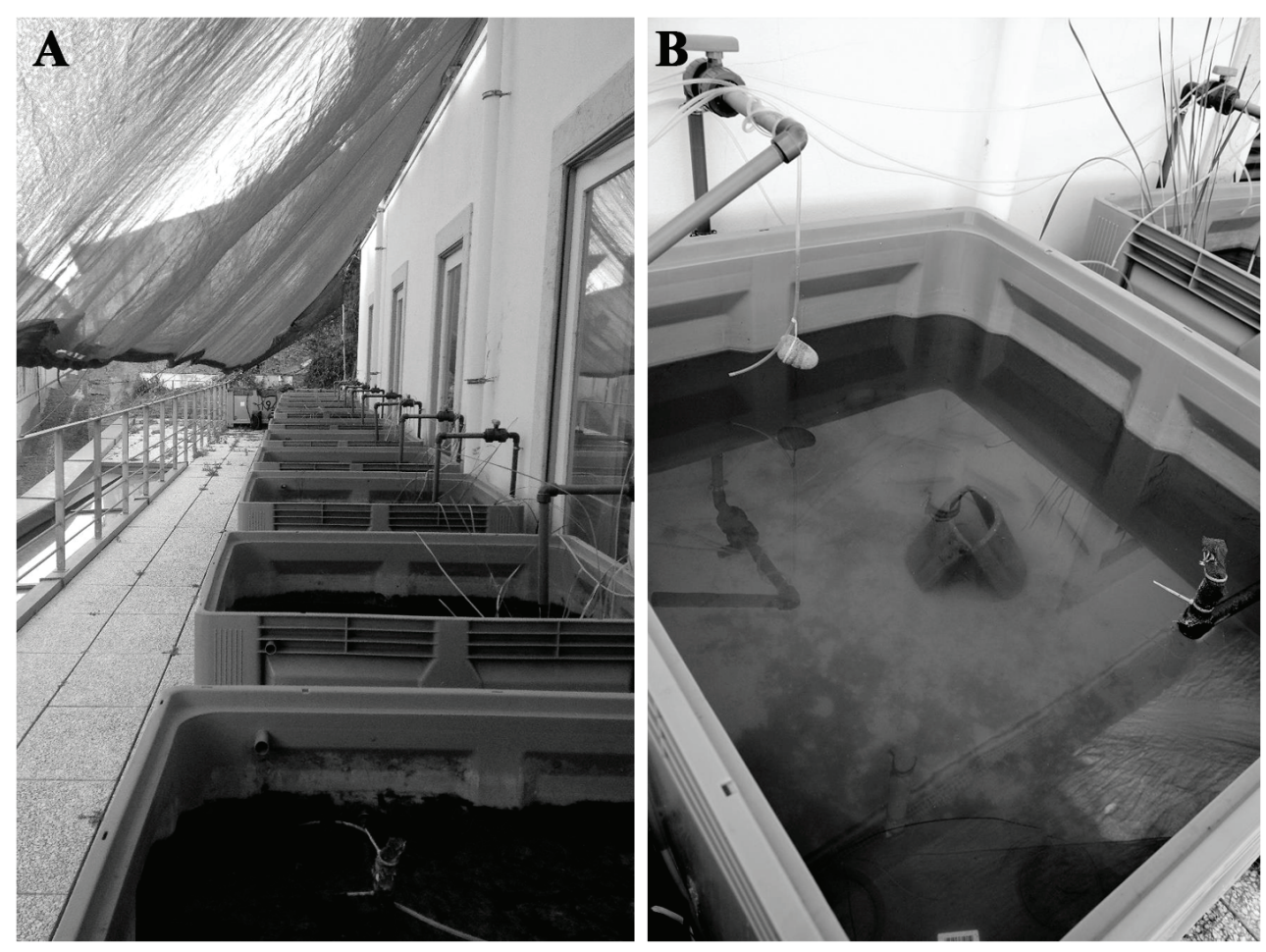

Figure 1. A - General view of the set of outdoor tanks where the experimental trials were held; B - Detail of a tank showing the typology of the shelter, consisting of two roof tiles in a cone-like position. Vista general del conjunto de tanques al aire libre donde se realizaron los ensayos experimentales; $B$ - Detalle de un tanque que muestra la tipología del refugio, que consiste en dos tejas en una posición similar a un cono. 


\section{METHODS}

\section{Experimental design and data collection}

The experiments were conducted in July 2016 at the facilities of Parque Natural do Vale do Guadiana from Instituto da Conservação da Natureza e das Florestas (ICNF). The specimens of saramugo came from stocks kept there for ongoing efforts to maintain the species ex-situ and the bleak from wild populations. Individuals of different species were not in contact prior to the acclimatization necessary to the experiment. All the trials followed the ethical guidelines for the care and use of animals in laboratory, established by Directive 2010/63/EU on animal welfare (EU, 2010). After being used in the experiments, bleak individuals were anesthetized and sacrificed. Saramugo individuals were returned to the original stock at ICNF facilities. All fish were measured (total length, $\mathrm{mm}$ ) immediately before being used in the experiments and each individual was not used more than once.

Experiments were held in outdoor tanks (length $=1.20 \mathrm{~m}$; width $=1.0 \mathrm{~m}$; height $=0.8 \mathrm{~m}$; volume $=600 \mathrm{~L}$ ), permanently aerated (Fig. 1A). Before and during the experiments, fish were maintained under natural light (approximately L:D 14:10 hours) and temperature conditions $\left(22.5 \pm 0.8^{\circ} \mathrm{C}\right)$. Physicochemical measurements were performed once per day during the experiments, including conductivity ( $\mu \mathrm{s} / \mathrm{cm}), \mathrm{pH}$ and dissolved oxygen $(\mathrm{mg} / \mathrm{L})$ and also water transparency (Secchi disk depth, $m$ ) to ensure stable and comparable conditions. During the trials, the conductivity varied from 510 to $548 \mu \mathrm{s} / \mathrm{cm}$, the dissolved oxygen from $9.7-10.5 \mathrm{mg} / \mathrm{L}$ and the $\mathrm{pH}$ ranged from $8.2-9.5$ (excluding one rejected replicate due to high turbidity). Two roof tiles (440 × $262 \times 84 \mathrm{~mm}$ each roof tile) in a cone-like position were placed in the centre of each tank to be used as shelter (Fig. 1B).

Experimental design constituted of two groups of fish, 3 replicates (tanks) each as follows:

i) Control group $(\mathrm{CG})-\mathrm{n}=30$ saramugo individuals (mean total length $(\mathrm{TL})=48.0 \pm 7.4$ mm S.D.);

ii) Experimental group (EG) $-\mathrm{n}=30$ saramugo individuals ( $\mathrm{TL}=44.9 \pm 9.3 \mathrm{~mm}$ S.D. $)$ and $\mathrm{n}=15$ bleak individuals $(\mathrm{TL}=113.0 \pm 29.5$ $\mathrm{mm}$ S.D.).

The control and experimental groups composition took into account the minimum number of saramugo individuals known to form a shoal $(\mathrm{N}=$ 30; Carrapato, personal observations) and the approximate size of individuals at the first sexual maturation (Ribeiro et al., 2000; Masó et al., 2016), in order to guarantee the maturity of all individuals involved. Previous observations indicate that from 15 individuals (either in an 400 $\mathrm{L}$ aquarium or $600 \mathrm{~L}$ tank), the bleak does not show signs of stress (agitation, constant sudden moves), evidencing a certain comfort for this number, i.e., individuals presented a stable and calm behavioural pattern, swimming in a slow and steady manner (personal observations). Tested bleak groups randomly included individuals of different size classes, reflecting, as far as possible, the populations found in the wild.

This study approached an endangered species, the saramugo, which restricted the number of individuals available for experiments. For this reason, it was not possible to include a superior number of replicates. Furthermore, one replicate (tank) of the EG had to be excluded from the analysis because water transparency was not ideal for video recording and visualization (Secchi depth of $\sim 0.8 \mathrm{~m}$ in ideal conditions vs Secchi depth of $\sim 0.3 \mathrm{~m}$ in the excluded tank), and this could influence fish behaviour.

Behaviour observations were performed through videos, recorded with underwater cameras (GoPro Hero 4.0 Black). The cameras were placed in a corner of each tank in order to maximize the observation area and the visibility of the shelter's interior. Both groups (CG and EG) were recorded once per day over 3 days, in the morning (from 10:00 $\mathrm{h}$ to 11:30 h). After a day of acclimatization for all the individuals, video recording ran continuously for 90 minutes (min), simultaneously and independently for each replicate.

\section{Behavioural categories}

Five behavioural categories (shelter use, shoaling, space use, swimming and biotic interactions) were defined in order to analyse fish behavioural 
Table 1. Behavioural categories and respective measured variables defined to analyse saramugo activity pattern, shelter use and its possible interactions with bleak. Categorías comportamentales y variables medidas en relación a ellas, definidas para analizar los patrones de actividad del jarabugo, el uso del refugio y las posibles interacciones con el alburno.

\begin{tabular}{|c|c|c|}
\hline & Measured variables & Category \\
\hline \multirow{8}{*}{ 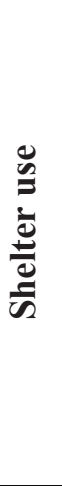 } & $<10 \%$ individuals in the area near the shelter & \multirow{3}{*}{ Shelter use (intensity) } \\
\hline & $10 \%-50 \%$ individuals in the area near the shelter & \\
\hline & $>50 \%$ individuals in the the area near the shelter & \\
\hline & Shelter use & Total rate of use \\
\hline & $<10 \%$ individuals inside shelter & \multirow{3}{*}{$\begin{array}{l}\text { Area near shelter } \\
\quad \text { (intensity) }\end{array}$} \\
\hline & $10 \%-50 \%$ individuals inside shelter & \\
\hline & $>50 \%$ individuals inside shelter & \\
\hline & Area near the shelter & Total rate of use \\
\hline \multirow{3}{*}{ 我 } & Monospecific group & \multirow{3}{*}{ Shoaling } \\
\hline & Heterospecific group & \\
\hline & Disperse individuals & \\
\hline \multirow{6}{*}{ : } & Surface & \multirow{3}{*}{ Space use } \\
\hline & Water column & \\
\hline & Bottom & \\
\hline & Static individuals & \multirow{3}{*}{ Swimming } \\
\hline & Normal swimming & \\
\hline & Fast swimming & \\
\hline \multirow{4}{*}{ 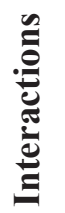 } & Individual intraspecific & \multirow{4}{*}{$\begin{array}{c}\text { Agressive } \\
\text { or } \\
\text { Non-agressive }\end{array}$} \\
\hline & Individual interspecific & \\
\hline & Social intraspecific & \\
\hline & Social interspecific & \\
\hline
\end{tabular}

patterns (Table 1). Each category was evaluated through different variables described below and quantified during the observation of the video records and mainly focused on saramugo behaviour. Excluding biotic interactions, all behavioural categories were exclusively quantified outside the shelter structure.

Shelter use was divided in two sections: the space inside the roof tiles (shelter) and the area surrounding the roof tiles in close proximity to them (near the shelter) which represented a visually estimated distance of approximately 10 to 15 $\mathrm{cm}$. The evaluation of these behaviour categories was made in two different ways. Firstly, considering the number of individuals occupying the space inside the shelter and near the shelter (intensity of use), the time when there were less than $10 \%$ of the individuals inside/near the shelter, 10 to $50 \%$ of the individuals inside/near the shelter and more than $50 \%$ of the individuals inside/near the shelter 
was quantified. Secondly, the total rate of use was also quantified, accounting for the total time when the shelter or the area near the shelter was occupied, independently on the number of individuals occupying it. The choice of analysing the space near the shelter as a component of shelter use was based on previous observations where the saramugo showed to be highly dependent on shelter structures.

Shoaling refers to events of fish aggregation on a limited space within the tank, when individuals swim or maintain their position, intentionally remaining near each other in an interactive way and showing evidences of social awareness (i.e. adjustment of swimming behaviour to remain close to the group). Here, we considered three variables in order to analyse shoaling: monospecific shoal (group of individuals exclusively constituted by the saramugo); heterospecific shoal (aggregation of individuals of both the bleak and the saramugo) and dispersed, when saramugo individuals isolated themselves from the group and swam further in the tank, considerable increasing the distance to the nearest conspecific ( $>15 \mathrm{~cm}$, visually estimated) without any signs of social awareness.

Space use evaluated how the individuals used the tank along a vertical gradient of water depth, considering three layers: surface, water column and bottom, accounting for the time spent in each layer. These three layers were visually estimated based on tape attached to the tank wall, opposite to the camera, signalling the following depths measured from the bottom: 0 to $20 \mathrm{~cm}$ (bottom), 20 to $60 \mathrm{~cm}$ (water column), 60 to $80 \mathrm{~cm}$ (surface).

Swimming category intended to analyse whether individuals were consistently moving (normal swimming) or stayed relatively still in the same place for more than 2 seconds (static). Additionally, fast swimming events refer to a fast and sudden change in the swimming direction of one individual or an entire group for no more than one second.

Interactions analysis refer to social and individual events including aggressive and non-aggressive behaviour performed by the saramugo and the bleak. Interactions involving 2 specimens were considered individual, while events involving 3 or more individuals were registered as social. Aggressive interactions described rapid movements of usually one individual towards another or to a group of individuals, ultimately resulting on the displacement of the targeted individual or on the spatial disruption of the group. Non-aggressive events referred to an oriented but slower approach between individuals, showing no signs of intimidation.

Fast swimming events and interactions were counted based on the frequency of occurrence of these events. The remaining variables were measured in time and analysed as a percentage of the total observation time

\section{Data analysis}

The GoPro Hero 4.0 Black setting allowed to automatically separate each video record of 90 min in sets of 5 different video files of approximately $18 \mathrm{~min}$ (hereafter called sample units). The analysis and systematization of the $90 \mathrm{~min}$ video records were made separately for each 18 min sample using JWatcherTM software (Dan Blumstein, Chris Evans and Janice Daniel, Animal Behaviour Laboratory, Macquarie University, Sydney, Australia). Each sample unit to be analysed was played for 5 times (the number of behavioural categories considered for analysis) and related variables accounted during its visualization. The first sample unit ( $\sim 18 \mathrm{~min})$ of each 90 min record set was never considered for analysis since fish natural behaviour was likely disturbed by the installation of the camera in the tank. Video records were analysed until a reasonable number of sample units was achieved, parallel to a consistent behaviour pattern of the species, showing no further differences in their performance for a considerable amount of time. For this reason, total time analysed for EG was $371.1 \mathrm{~min}$ (21 sample units) and $265.5 \mathrm{~min}$ (15 sample units) for CG.

Mann-Whitney U tests and Kruskal-Wallis $\mathrm{H}$ tests were used to check for significant differences over time (day 1, 2 and 3 of the experiments) and between replicates within $\mathrm{CG}$ and $\mathrm{EG}$, including all variables. Afterwards, Mann-Whitney $U$ tests were conducted by category, in order to compare trials (CG vs EG) and assess differ- 
ences between specific variables. Wilcoxon-signed rank tests were performed on variables composing each behavioural category individually within each group (CG or EG) to evaluate possible contrasts between variables translating the same behavioural topic. Spearman rank correlations were performed to assess possible relations between all behavioural variables per group $(|\mathrm{r}|>0.5 ; P<0.05)$.

Drawing upon results of the initial statistical analyses, a path analysis with structural equation modelling (SEM) methodology was used to identify the most plausible interaction pathways between the behavioural pattern of saramugo and the presence of the bleak. This is a highly flexible multivariate statistical approach able to test and estimate direct/indirect relationships within complex systems on the basis of a priori hypothesized relationship patterns among a set of observed (measured) and/or unobserved (latent) variables (MacCallum \& Austin, 2000; Shipley, 2002).

Three alternative theoretical models were designed to evaluate the influence of the bleak presence on the behavioural pattern of saramugo, specifying that (1) both the swimming activity and shelter use were directly influenced by the presence of the bleak, while space use and individuals dispersion were influenced indirectly; (2) the presence of the bleak influenced directly the swimming activity, while space use, shelter use and dispersion were indirectly influenced; (3) the presence of the bleak influenced directly the shelter use, whereas space use, swimming and dispersion were influenced indirectly

In the construction of the models, the presence of bleak was treated as an independent (exogenous) variable. The variables associated with the behavioural categories evaluated (see Table 1) were considered response variables (endogenous - simultaneously independent/dependent or only dependent), though interactions were not included in this analysis due to insufficient N. These variables were included in the 3 theoretical models in different ways: i) directly measured variables; ii) latent variables, corresponding to the behavioural categories, not directly observed but rather inferred from the observed variables (directly measured); iii) composite variables, corresponding to the first axis of Principal Com- ponents Analyses (PC1) performed separately for each latent variable, reducing their dimensionality and simultaneously minimizing the number of variables in the analysis, still ensuring their representativeness by a high percentage of explained variance $(>70 \%)$.

Accordingly, a large number of model configurations were tested, but only the three configurations with the best results were retained and compared. The retained models needed to maximize the explanatory power (i.e., retain as many paths as possible), as long as all paths were significant at $P \leq 0.05$ and the global model was acceptable, presenting good fit values. To do so, each model was tested and the weakest paths (or non-significant) were sequentially removed using a backward selection, until the best model was achieved (e.g. McManamay et al., 2015). Afterwards, the most plausible models for each set were selected by comparing their goodness-of-fit.

To overcome possible problems arising from a modest sample size, the discrepancy function for the Asymptotically Distribution-Free method was used in parameter estimation. The goodness-of-fit of the models was examined through the chi-square test (Kline, 2010), the root mean square error of approximation (RMSEA) (Hu \& Bentler, 1999) and the comparative fit index (CFI) (Hu \& Bentler, 1999).

Prior to models testing, endogenous variables were either $\log (\mathrm{x}+1)$ (linear measurements) or $\arcsin$ [sqrt (x)] (percentages) transformed to improve normality (Legendre \& Legendre, 1998). The exogenous variable bleak presence was coded as dummy/categorical (Freedman, 2009). Variables were also screened for egregious multicollinearity using Spearman Rank Correlation analysis $(|\mathrm{r}| \geq 0.7 ; P<0.05)$.

Path analyses were performed using the software Spss Amos 24. For the other statistical analyses significance level was set for $\alpha=0.05$ and tests were performed using Statistica 10 software.

\section{RESULTS}

The bleak did not occupied the shelter, which was exclusively used by the saramugo. Saramugo individuals were quite elusive, exhibiting a 
A

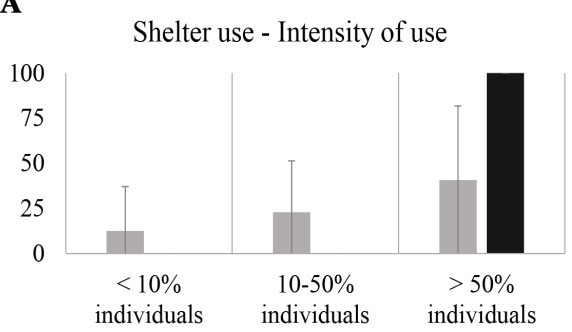

B

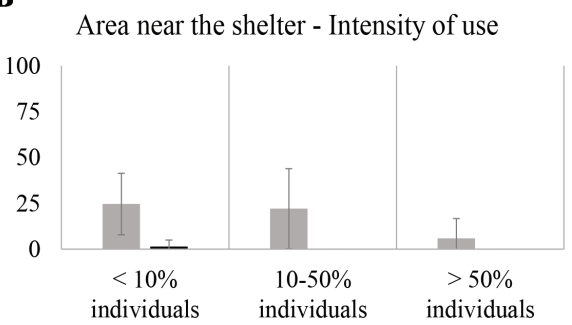

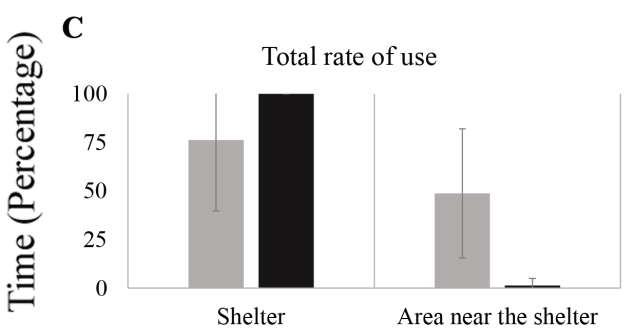

D

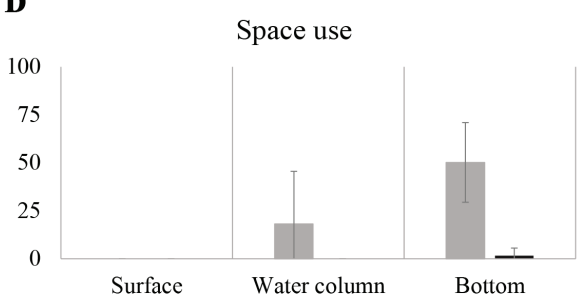

E

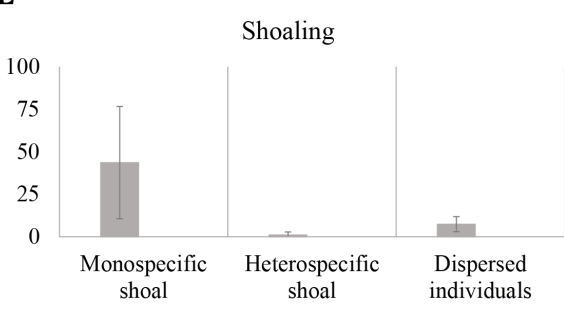

F

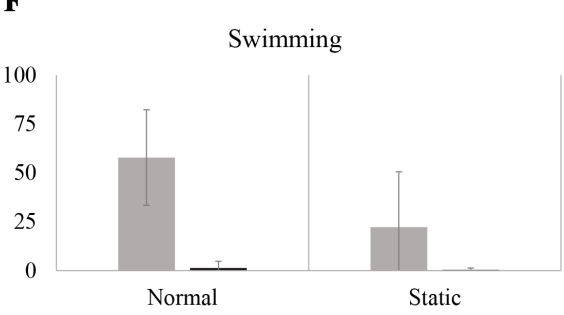

G

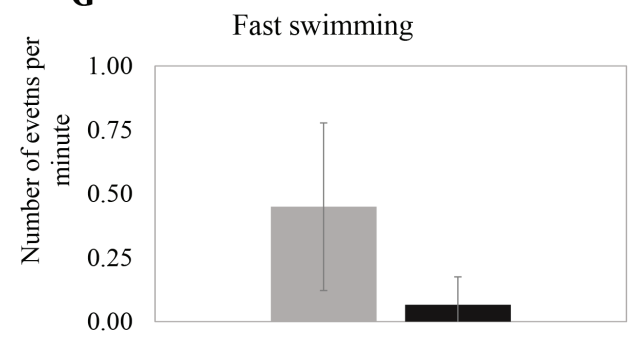

$\square \mathrm{EG}$ - $\mathrm{CG}$

Figure 2. Saramugo behavioural patterns in the Control Group (CG; $N=15)$ and the Experimental Group (EG; $N=21)$, including all measured variables. Mean percentage of the observation time ( \pm S.D.) for shelter use (intensity of use - A; total rate of use $-C)$, area near the shelter use (intensity of use - B; total rate of use - C), space use (D), shoaling behaviour (E) and swimming behaviour (F). Fast swimming events per minute ( \pm S.D.) $(G)$. Intensity of shelter use and area near the shelter includes the information on the number of individuals occupying the shelter and the area near the shelter $(<10 \%$ of individuals; $10-50 \%$ of individuals, $>50 \%$ of individuals $)$. Total rate of use refers to the time when the shelter and the area near the shelter were occupied, independently on the number of individuals occupying it. These figures refer only to saramugo behaviour pattern. Patrones de comportamiento dej jarabugo en el grupo de control (CG; $N=15)$ y el grupo experimental $(E G ; N=21)$, incluidas todas las variables medidas. Porcentaje medio del tiempo de observación ( $\pm D E$ ) para el uso de refugio (intensidad de uso - A; indice de uso total - C), área cercana al refugio (intensidad de uso - B; indice de uso total - C), uso del espacio (D), comportamiento de cardumen (E) y comportamiento de natación (F). Eventos de natación rápido por minuto $( \pm D E)(G)$. La intensidad del uso de refugio y el área cercana al refugio incluye la información sobre el número de peces que ocupan el refugio y el área cercana al refugio (<10\% de las personas, $10-50 \%$ de las personas, $>50$ $\%$ de las personas). La tasa total de uso se refiere a la ocupación del refugio y el área cercana al refugio, independientemente del número de peces que lo ocupan. Estas figuras se refieren solo al patrón de comportamiento del jarabugo. 
substantial occupation of the shelter and nearby areas in both the CG and the EG. Specifically, the CG clearly showed a high dependency on the shelter, with $50 \%$ of the saramugo individuals occupying this structure for more than $50 \%$ of the saramugo individuals for the whole observation time (Fig. 2A). This significantly contrasts with the results from EG, in the presence of the bleak, where this percentage decreased to $40 \%$ of the observation time (Mann-Whitney $\mathrm{U}$ test, $\mathrm{U}=$ 7.5, $\mathrm{N}_{\mathrm{EG}}=21, \mathrm{~N}_{\mathrm{CG}}=15, P<0.0001$; Fig. 2A). Considering the total rate of shelter use, the difference between CG and EG is also noteworthy, with a significant decrease from $100 \%$ to approximately $76 \%$ of the observation time ( $\mathrm{U}=$ $60, \mathrm{~N}_{\mathrm{EG}}=21, \mathrm{~N}_{\mathrm{CG}}=15, P<0.001$; Fig. 2C). The area near the shelter was also largely occupied in $\mathrm{EG}$, for approximately $50 \%$ of the total observation time, contrasting with a $1 \%$ occupation in the $\mathrm{CG}\left(\mathrm{U}=18, \mathrm{~N}_{\mathrm{EG}}=21, \mathrm{~N}_{\mathrm{CG}}=15, P<0.0001\right.$; Fig. $2 \mathrm{C}$ ). In the $\mathrm{CG}$, this $1 \%$ occupation was represented by a small number of individuals ( $<$ $10 \%$ ) swimming around the shelter structure and it never exceeded 3 individuals at the same time (Fig. 2B), while the rest of the group remained inside the shelter. In the EG, the intensity of occupation of the area near the shelter was substantial, including events of more than $50 \%$ of the group for approximately $6 \%$ of the observation time and 10 to $50 \%$ of the individuals for approximately $22 \%$ (Fig. 2B).

Whenever outside the shelter, either in the EG and $C G$, the saramugo individuals preferably used the bottom of the tank. Moreover, saramugo individuals in the $\mathrm{CG}$ sporadically outside the shelter exclusively used the bottom layer (Fig. 2D). Contrastingly, saramugo individuals in the EG moved up to the water column, occupying it for almost $20 \%$ of the observation time $(U=60$, $\mathrm{N}_{\mathrm{EG}}=21, \mathrm{~N}_{\mathrm{CG}}=15, P<0.001$; Fig. 2D). Particularly in this situation, when saramugo individuals in the EG use the water column in addition to the bottom, widening their space range, they tend to do it monospecific shoaling (Spearman's rank correlation, $|\mathrm{r}| 0.64, \mathrm{~N}=21, P<0.01)$. Nevertheless, regardless of saramugo space use, individuals spent approximately $40 \%$ of the observation time monospecific shoaling in the EG (Fig. 2E). In addition to this, individuals also grouped inside the shelter for a considerable proportion of time (see Fig. 2A, showing more than $50 \%$ of the individuals occupying the shelter for approximately $40 \%$ of the observation time). This grouping behaviour was also clear in the $\mathrm{CG}$, once individuals remained in a large group ( $>50 \%$ of the individuals; Fig. 2A) inside the shelter for the total observation time. However, data did not show this information directly since monospecific group and shoaling were only quantified outside the shelter. Individuals did not disperse often, however, there are significant differences between the EG and the CG, where the dispersed percentage of time decreases from approximately $7 \%$ to $0 \%$ (Fig. 2E). Moreover, individuals' dispersion in the EG was lower when the shelter was occupied for a greater number of individuals $(>50 \%)$ $-|\mathrm{r}|=-0.56, \mathrm{~N}=21, P<0.05)$. The heterospecific shoal represented no more than $1 \%$ of the observation time in EG (Fig. 2E) and it was only represented by events of smaller bleak individuals

Table 2. Interspecific interactions between bleak and saramugo, and intraspecific interactions between the bleak (frequency per hour. Mean \pm S.D.; Maximum; $\mathrm{N}=21$ ). Interacciones interespecificas entre el alburno y el jarabugo e interacciones intraespecificas entre el alburno (Frecuencia por hora, Media \pm DE; Máximo, $N=21$ ).

\begin{tabular}{lcccccc}
\hline & \multicolumn{3}{c}{ Interspecific } & \multicolumn{3}{c}{ Intraspecific } \\
& Individual & \multicolumn{2}{c}{ Social } & Individual & \multicolumn{2}{c}{ Social } \\
& Aggressive & Aggressive & Non-aggressive & Aggressive & Aggressive & Non-aggressive \\
Mean \pm SD & $1.0 \pm 0.5$ & $4.8 \pm 0.9$ & $2.6 \pm 0.6$ & $8.1 \pm 1.2$ & $1.3 \pm 0.5$ & $0.7 \pm 0.4$ \\
Maximum & 6.8 & 13.5 & 6.8 & 20.3 & 6.8 & 6.8 \\
\hline
\end{tabular}


joining or approaching the saramugo group for a few seconds. Monospecific shoal and group represented a consistent behaviour to the saramugo, when compared to the other shoaling variables with much lower expression (EG dispersed: $\mathrm{Z}=$ $3.59, \mathrm{~N}=21, P<0.001$; EG heterospecific shoal: $\mathrm{Z}=4.01, \mathrm{~N}=21, P<0.001)$.

Saramugo's swimming behaviour was more pronounced in the EG, due to the lack of space use outside the shelter in the CG. In the EG, individuals spent considerably more time moving (normal swimming, approximately $60 \%$ ) than motionless (static, approximately $20 \%)(\mathrm{Z}=3.98, \mathrm{~N}=21, P$ $<0.0001$; Fig. 2F). Saramugo individuals in the EG showed significantly more fast swimming events relatively to $\mathrm{CG}\left(\mathrm{U}=22 \mathrm{~N}_{\mathrm{EG}}=21, \mathrm{~N}_{\mathrm{CG}}=\right.$ 15, $P<0.0001$; Fig. 2G). Monospecific shoal showed a positive correlation with both normal swimming (EG: $|\mathrm{r}|=0.85, \mathrm{~N}=21, P<0.001$ ) and static (EG: $|\mathrm{r}|=0.52, \mathrm{~N}=21, P<0.05$ ).

Direct interactions between individuals only occurred in the presence of bleak and, overall, they were triggered by this species. The number of interactions initiated by saramugo individuals was very low, always performing non-aggressive behaviour and therefore were not considered for analysis. Bleak individuals exhibited mostly aggressive interactions which dominated over non-aggressive ones $(\mathrm{Z}=2.5, \mathrm{~N}=21, P<0.001)$. On average, intraspecific interactions within bleak individuals were slightly more frequent than interspecific with saramugo (Table 2). Generally, they represented individual aggressive interactions as chases of one individual towards another, being the most significantly common type of intraspecific aggressive event $(\mathrm{Z}=3.6, \mathrm{~N}$ $=21, P<0.001)$. The number of interspecific social aggressive interactions were significantly higher than social non-aggressive $(\mathrm{Z}=2.4, \mathrm{~N}=$ $21, P<0.05)$. The first typically described a quick movement of one bleak individual towards a group of saramugo, disrupting it, often happening while the group was occupying the shelter. The second usually involved minor sized bleak individuals which slowly approached the saramugo group for a while, generally in the shelter's proximity where the group frequently was. Other interactions showed little expression and did not present an evident pattern.

The three theoretical models designed to explain the effects of bleak presence on the behavioural pattern of saramugo were tested for their

Table 3. Results from the goodness-of-fit tests for the 3 theoretical models designed to explain the effects of bleak presence on the behavioural pattern of saramugo. Tests used included the chi-square test $\left(\chi^{2}, d f=\operatorname{degrees}\right.$ of freedom, $P=$ significance level), the root mean square error of approximation (RMSEA) and the comparative fit index (CFI). The best model is highlighted in grey. Resultados de las pruebas de bondad de ajuste para los 3 modelos teóricos diseñados para explicar los efectos de la presencia de alburno en el patrón de comportamiento de jarabugo. Las pruebas utilizadas incluyeron la prueba de chi-cuadrado $\left(\chi^{2}\right.$, $\mathrm{df}=$ grados de libertad, $\mathrm{P}$ = nivel de significación), el error cuadrático medio de aproximación (RMSEA) y el índice de ajuste comparativo (CFI). El mejor modelo se resalta en gris.

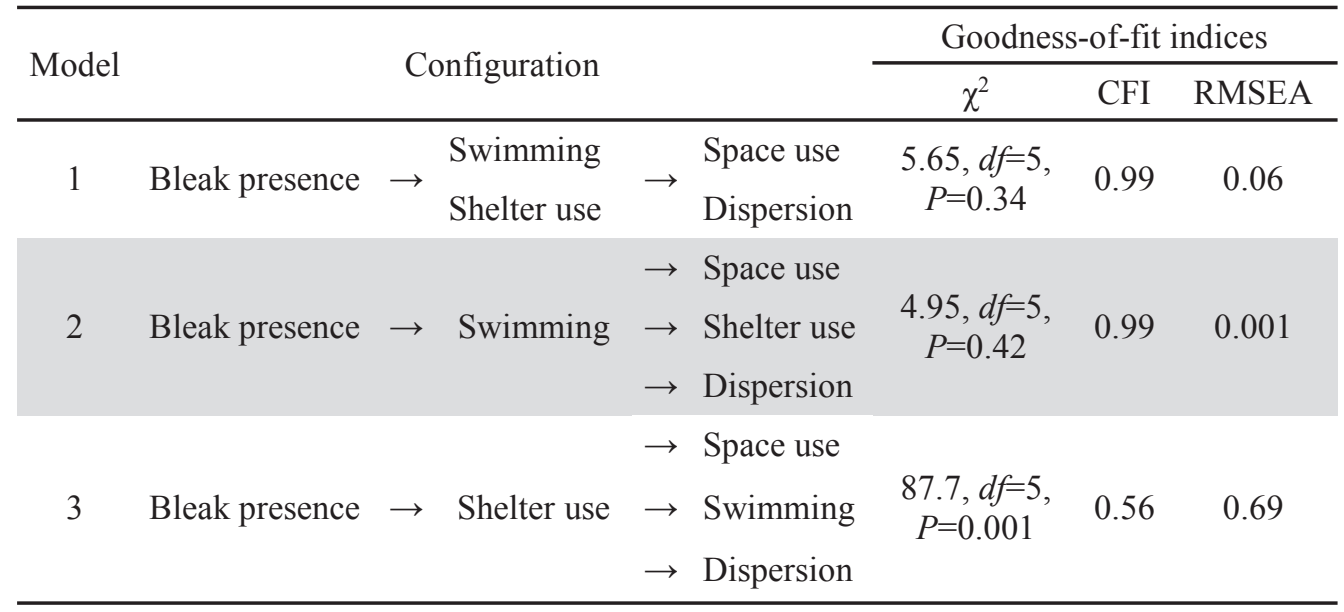




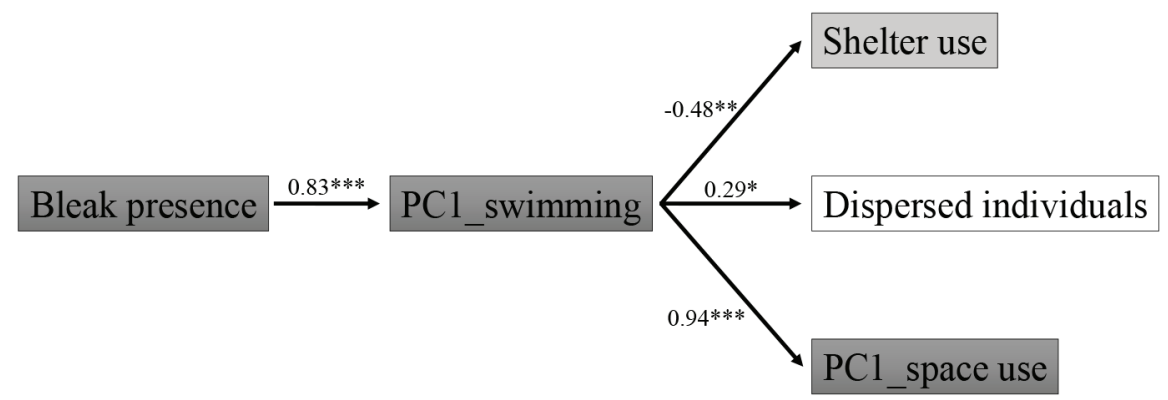

Figure 3. Path diagram summarizing the selected model to explain the effects of bleak presence on the behaviour of saramugo. The Standardized Coefficients for each path are shown, along with their significance level $(* * * P<0.001 ; * * P<0.01 ; * P<0.05)$. PC1 refers to composite variables and represent the first axis of Principal Components Analyses performed with the measured variables of each behavioural category. Behavioural variables and categories are listed in Table 1 . The grayscale reflects the intensity and significance of the effects of bleak presence. Diagrama de vías que resume el modelos seleccionado para explicar los efectos de la presencia del alburno en el patrón de comportamento del jarabugo. Se muestran los coeficientes estándar para cada vía, así como su nivel de significancia $(* * * \mathrm{P}<0.001 ; * * \mathrm{P}<0.01 ; * \mathrm{P}<0.05)$. PC1 se refiere a las variables compuestas y representa el primer eje del análisis de componentes principales realizado con las variables de cada categoría comportamental. Las variables y categorías de comportamiento se mencionan en la Tabla 1. La escala de grises refleja la intensidad y la significancia de los efectos de la presencia del alburno.

goodness-of-fit and the values obtained clearly allowed to select one model that presented simultaneously non-significant values for the chi-square test, high CFI values and reduced RMSEA values, producing the best fit to the data (Table 3).

The interpretation of the path diagram for the selected model 2 revealed a strong positive direct effect of bleak presence on the swimming activity of saramugo (0.83) (Fig. 3). In turn, this increased swimming activity had a strong positive direct effect on the space use (0.94), a moderate negative effect on the shelter use (-0.49) and a small positive effect on the dispersion of saramugo individuals (0.29). Therefore, the presence of bleak produced only indirect effects on the space use (0.79), refuge use (-0.40) and dispersion of individuals $(0.29)$. The wider space use and the dispersion of individuals was a consequence of the higher swimming activity induced by the presence of the bleak. On the other hand, the reduction in saramugo shelter use occurred mainly through changes in individuals' activity and not by direct bleak competition.

\section{DISCUSSION}

The presence of the bleak may be responsible for changing the behavioural patterns of saramugo, mostly by increasing individual's activity rate and decreasing sheltering time, while the native species showed to be particularly dependent on shoaling and sheltering. Additionally, the general aggressive behaviour of this invasive species, both towards the saramugo or conspecifics, contrasted with the passive behaviour of the native species, clearly pointing to a potential dominance of the bleak over the saramugo if they were to coexist in the wild.

Saramugo is a shoaling species with a strong gregarious behaviour, permanently grouping with conspecifics rather than with the bleak. Monospecific shoaling seemed to be a crucial and constant feature for the saramugo, independently on the presence of the bleak, which points to the strong role of social intraspecific relationships to this species. Small fish as the saramugo may particularly benefit from shoaling, once it has the potential to decrease predation risks, increase reproductive efficiency and reduce the energetic costs of movement, ultimately enhancing survival (Pitcher, 1979; Ward et al., 2002; Camacho-Cervantes et al., 2014). Saramugo rarely shoaled with the bleak and this kind of behaviour was only represented by smaller bleaks momentarily joining the saramugo group in all the observed events. While not specifically considered here, size can play an important role in heterospecific shoaling (Krause et al., 2000a) and 
average size of saramugo was considerable lower than bleak. However, smaller bleak individuals were similar-sized compared to saramugo, which may explain why they sporadically grouped. Interestingly, when both species grouped, individuals were assorted by species within the shoal, that is, individuals of different species were not mixed, and instead they formed a heterogeneous group constituted by the two species. Several other shoaling fish species show preference towards conspecifics, namely other cyprinids such as the chub (Leuciscus cephalus), the European minnows (Phoxinus phoxinus) (Ward et al., 2002) and the zebrafish (Danio rerio) (Saverino et al., 2009). The propensity to shoal with conspecifics may be related with evolutionary mechanisms to reduce predator's ability to catch fish by minimizing phenotypic oddity (Landeau \& Terborgh, 1986), in addition to increasing reproductive and foraging success (Saverino et al., 2009) and minimizing competition between individuals within the group (Ward et al., 2002). Fish shoals may be species-specific or size-specific (e.g. Hoare et al., 2000); in this study results, saramugo shoaling seemed to be driven by both drivers but with emphasis on species identity. The overlapping of species identity importance on shoaling choice and therefore the recognition of conspecifics may be adaptive since they share the same requirements in terms of diet and habitat (Ward et al., 2002).

Sheltering was, as with shoaling, a key behaviour feature for saramugo, given the high proportion of time they spent in the shelter areas in both performed trials. This dependence on shoaling and sheltering represent behavioural defences of small fish species without morphological defences such as spines and sticklebacks (Krause et al., 2000b). Furthermore, small fish as saramugo typically use habitats with a high shelter availability, making them less susceptible to predation, which is in accordance with the use of habitats with coarser substrate by the saramugo (Ribeiro et al., 2000; Ilhéu, 2004; Ilhéu et al., 2016). However, in the presence of the bleak, saramugo exhibited a significant decrease in shelter use, translated by both the decreased time spent sheltering and the decreased number of individuals occupying it. In this trial, this was accompa- nied by an increase in the occupation of the area near the shelter. This behavioural pattern and the life history traits of this species (Ribeiro et al., 2000) point to a dependence on shelter structures and suggests that those structures may be a valuable resource composing the preferred habitats for saramugo. In the presence of the bleak, this species clearly spent less time occupying it, which may indicate a possible shift in space use to less suitable habitats in case of coexistence. Similar results concerning the displacement of the European bulhead from shelter places to less suitable habitats by gobies were found (Van Kessel et al., 2011). The behaviour of staying under shelter almost permanently in the CG could suggest some kind of discomfort for the saramugo individuals, however these may represent the actual low fish density found in natural populations for this species. Sampling in the field showed really low capture numbers for the saramugo (unpublished data).

Saramugo individual dispersion from the shoal, (i.e. a single individual swam across a wider area separating from the group) exclusively occurred when the bleak was present. This was accompanied by a substantial increase in fast swimming events (i.e. sudden and fast movements) and a wider use of the space in the tank, including the bottom and the water column. This largely contrasts with the $\mathrm{CG}$, showing total absence of dispersion and water column occupation. Furthermore, in the EG, the occupation of the water column by the saramugo only occurred while individuals were in a group and the group was constantly moving (normal swimming). Contrarily, the occupation of the bottom layer in the EG was associated with a quieter swimming behaviour, as was the general behaviour of the CG. Those differences from the control behaviour pattern suggest that the presence of the bleak may led to an increment in the activity levels of saramugo individuals. The bleak generally showed an excited behaviour, moving faster and wider than the saramugo, while exploring the whole available space in the tank.

Several fish species are known to modify their swimming and shoaling behaviour when presented with novel stressful situations (Sadoul et al., 2104). The increase on fish activity may be 
related to the performance of similar behaviour with more active fishes who may find food patches more rapidly and be more confusing to predators (Pritchard et al., 2001), but may also be pointed as a sensitive indicator of stress (Schreck et al., 2011). Therefore, the shift in the behavioural pattern of saramugo observed in the presence of bleak, regarding categories such as swimming, space use and dispersion, could represent a stress indicator.

Bleak individuals were much more aggressive than the saramugo, concerning both intraspecific and interspecific interactions, with is in accordance with previous studies for this species describing intraspecific nipping behaviour (Haberlegner, 1988). In fact, saramugo individuals never exhibited attack events toward any other fish, either conspecifics or the bleak. Considering interspecific aggressive interactions triggered by the bleak, they often resulted in the displacement of the saramugo group from the shelter, even if for a short period of time, after which the individuals returned to the shelter. This kind of aggressive behaviour also happened while the group was feeding (personal observations). Despite feeding behaviour was not assessed in the present study, it is worth considering the possible consequences on saramugo trophic behaviour imposed by bleak aggressive traits and should be addressed in the future. Aggressiveness tended to increase with bleak individuals body size and, compared to the saramugo, the bleak may be at an advantage (Balshine et al., 2005). The mean size of the specimens used in the present study were significantly different between the two tested species and this may have influenced the observed behavioural patterns. Nevertheless, the size-structure of the groups is in accordance with natural populations found in the wild for both species; saramugo is a small-sized species $(<60$ $\mathrm{mm}$ fork length) (Ribeiro et al., 2000), contrarily to the bleak which presents a mean length of approximately $150 \mathrm{~mm}$ (Billard, 1997).

This disturbance is especially concerning because aggressive behaviour could be one of the most important causes of exclusion between species (Ortubay et al., 2002), and represents a source of stress which may lead to increased vulnerability to infections, disproportionate ener- getic expenditure and fitness costs (Beyer et al., 2010). Furthermore, behavioural interference may result in the displacement of native species from its indispensable resources, as food and habitat, resulting in a greater energetic cost, in order to avoid the species with a more aggressive behaviour (Almeida et al., 2014).

In spite of only showing exploratory and preliminary results, the present study highlights the relevant role that interference competition may play among the mechanisms through which invasive species impact native ones. Drawing from these results, we hypothesize that the presence of the bleak was responsible for some stimuli that increased the activity levels of saramugo; consequently, shelter use decreased, accompanied by a wider use of space, however social cohesion and protection through shoaling was maintained. Therefore, the coexistence with this invasive species may have the potential to modify the overall behaviour pattern of the saramugo, which may lead to indirect negative effects by promoting larger exposure to predators and greater fitness costs, increasing the risk of mortality. Nevertheless, we cannot exclude the possibility that the different fish density used in the trials (30 fish in the CG vs 45 fish in the EG) may have influenced the shift in the observed behavioural patterns rather than the presence of the invasive species per se. Furthermore, the behavioural response of the saramugo to the presence of another native species, especially if similar-sized to the bleak (e.g. Squalis pyrenaicus Günther, 1868), needs to be investigated in the future, in order to access the possibility of this species displaying the same behaviour alterations as in the presence of the bleak.

The possibility of coexistence of the saramugo and the bleak in the near future is particularly worrying during the dry summer season, when small streams from the Guadiana basin often become reduced to isolated pools constituting the only refuge for fish until river continuity is restored in the autumn. In these constraining circumstances, the interactions tend to increase and can play a crucial role in the persistence of native taxa and therefore species conservation. Because both species in this study may share habitat preferences and their distribution may 
overlap in a near future, the invasion of the bleak may have the potential to further weaken the condition of the already threatened saramugo populations, considerably increasing their vulnerability to other environmental threats, such as habitat degradation and non-native predators.

\section{CONCLUSIONS}

Even though direct competition between saramugo and bleak was not observed, the possible coexistence of these two species in the future may have a negative effect on the general behavioural pattern of saramugo, ultimately and indirectly increasing predation risks and stress vulnerability, which is particularly concerning since saramugo populations are currently already quite low. Considering the limiting number of saramugo individuals available to perform the experiments, the present study should be viewed as exploratory, pointing out relevant behavioural aspects that should be further investigated in order to confirm the present preliminary results.

The extrapolation of these experimental results to natural conditions should be done cautiously, once the magnitude of the interactions as well as the changes in the behavioural pattern of saramugo may highly depend on external factors such as the coexistence time, scale and environmental conditions like the availability of resources, which were not analysed in the present study.

Considering a possible future scenario of coexistence between saramugo and bleak, accompanied by a potentially habitat overlap, the investment in habitat rehabilitation actions that favour saramugo is fundamental, namely by promoting adequate refuge habitats. Management should also focus on restricting the access of invasive species, such as the bleak, to saramugo populations, reducing the number of interactions and leading to the mitigation of potential negative impacts.

\section{ACKNOWLEDGEMENTS}

This study was developed under the EU Life Programme (Conservation of the Saramugo, Anaecypris hispanica, in the Guadiana basin, Portugal - LIFE13 NAT/PT/000786) to whom we are grateful for the funding. Special thanks to the Instituto da Conservação da Natureza e das Florestas (ICNF) for providing $A$. hispanica specimens and the facilities where the trials took place.

\section{REFERENCES}

ALMEIDA, D. \& G. D. GROSSMAN. 2012. Utility of direct observational methods for assessing competitive interactions between non-native and native freshwater fishes. Fisheries Management and Ecology, 19 (2): 157-166. DOI: 10.1111/j.1365-2400.2012. 00847.x

ALMEIDA, D., R. MERINO-AGUIRRE, L. VILIZZI \& G. H. COPP. 2014. Interspecific aggressive behaviour of invasive pumpkinseed Lepomis gibbosus in Iberian fresh waters. PLoS ONE, 9 (2). DOI: 10.1371/journal.pone.0088038 ALVES, M. J., H. COELHO, M. J. COLLARES-PEREIRA \& M. M. COELHO. 2001. Mitochondrial DNA variation in the highly endangered cyprinid fish Anaecypris hispanica: Importance for conservation. Heredity, 87 (4): 463-473. DOI: 10.1046/j.1365-2540.2001. 00929.x

BALSHINE, S., A. VERMA, V. CHANT \& T. THEYSMEYER. 2005. Competitive Interactions between Round Gobies and Logperch. Journal of Great Lakes Research, 31 (1): 68-77. DOI: 10.1016/S0380-1330(05)70238-0

BEYER, K., R. E. GOZLAN \& G. H. COPP. 2010. Social network properties within a fish assemblage invaded by non-native sunbleak Leucaspius delineatus. Ecological Modelling, 221 (17): 2118-2122. DOI: 10.1016/j. ecolmodel.2010.06.002

BILLARD, R. 1997. Les poissons d'eau douce des rivières de France. Identification, inventaire et répartition des 83 espèces. Lausanne, Delachaux \& Niestlé, 192p.

BLANCO-GARRIDO, F., C. MIGUEL \& J. PRENDA. 2009. Jarabugo (Anaecypris hispanica) and freshwater blenny (Salaria fluviatilis): Habitat preferences and relationship with exotic fish species in the middle Guadiana basin. Limnetica, 28 (1): 139-148.

CAIOLA, N. \& A. DE SOSTOA. 2005. Possible reasons for the decline of two native toothcarps 
in the Iberian Peninsula: Evidence of competition with the introduced Eastern mosquitofish. Journal of Applied Ichthyology, 21 (4): 358-363. DOI: 10.1111/j.1439-0426.2005. 00684.X

CAMACHO-CERVANTES, M., A. F. OJANGUREN, A. E. DEACON, I. W. RAMNARINE \& A. E. MAGURRAN. 2014. Exotic invaders gain foraging benefits by shoaling with native fish. The Royal Society Publishing, 151: 769-780. DOI: 10.1098/rsos.140101

CARARPATO, C. \& F. RIBEIRO. 2012. Larval development of the Iberian cyprinid Anaecypris hispanica. Limnetica, 31 (1): 119-128.

COLLARES-PEREIRA, M. J., I. G. COWX, F. RIBEIRO, J. A. RODRIGUES, L. ROGADO \& L. MOREIRA DA COSTA. 1999. The status of Anaecypris hispanica in Portugal: Problems of conserving a highly endangered Iberian fish. Biological Conservation, 88 (2): 207-212. DOI: 10.1016/S0006-3207(98)00103-7

DE MIGUEL, R., PINO, E., RAMIRO, A., ARANDA, F., PEÑA, J. P., DOADRIO, I. \& C. FERNÁNDEZ-DELGADO. 2010. On the occurrence of Anaecypris hispanica, an extremely endangered Iberian endemism, in the Guadalquivir River basin. Journal of fish biology, 76(6): 1454-1465. DOI: 10.1111/j.1095-8649.2010.02574.x

DOADRIO, I., PEREA, S. y C. PEDRAZA-LARA. 2011. El jarabugo (Anaecypris hispanica Steindachner, 1866). Situación y estado de conservación. Madrid. Ministerio de Medio Ambiente y Medio Rural y Marino. 56 pages.

EU-EUROPEAN UNION. 2010. Directive 2010/63/EU of the European Parliament and of the Council of 22 September 2010 on the protection of animals used for scientific purposes. Official J. EU L 276: 33-79. URL: http://eur-lex.europa.eu/LexUriServ/ LexUriServ.do?uri=OJ:L:2010:276:0033: 0079:EN:PDF

FREEDMAN, D. A. 2009. Statistical models: theory and practice. Revised ed. Cambridge University Press, Cambridge, UK.

GARCÍA-BERTHOU, E., C. ALCARAZ, Q. POU-ROVIRA, L. ZAMORA, G. COENDERS \& C. FEO. 2005. Introduction pathways and establishment rates of invasive aquatic species in Europe. Canadian Journal of Fisheries and Aquatic Sciences, 62 (2): 453-463. DOI: 10.1111/j.1095-8649.2010.02574.X

GRABOWSKA, J., T. KAKAREKO, D. BLONSKA, M. PRZYBYLSKI, J. KOBAK, L. JERMACZ \& G. H. COPP. 2016. Interspecific competition for a shelter between non-native racer goby and native European bullhead under experimental conditions - Effects of season, fish size and light conditions. Limnologica, 56: 30-38. DOI: 10.1016/j.limno.2015. 11.004

HABERLEHNER, E. 1988. Comparative Analysis of Feeding and Schooling Behaviour of the Cyprinidae Alburnus alburnus (L., 1758), Rutilus rutilus (L., 1758), and Scardinius erythrophthalmus (L., 1758) in a Backwater of the Danube near Vienna. Hydrobiologia, 73 (5): 537-546. DOI: 10.1002/iroh. 19880730504

HERMOSO, V. M. CLAVERO, BLANCO-GARRIDO, F. \& J. PRENDA. 2011. Invasive species and habitat degradation in Iberian streams: An analysis of their role in freshwater fish diversity loss. Ecological Applications, 21 (1): 175-188. DOI: 10.1002/aqc. 1211

HOARE, D. J., G. D. RUXTON, J. G. J. GODIN \& J. KRAUSE. 2000. The social organization of free-ranging fish shoals. Oikos, 89 (3): 546-554. DOI: 10.1034/j.1600-0706.2000. 890314.x

HU, L. \& P. M. BENTLER. 1999. Cutoff criteria for fit indexes in covariance structure analysis: Conventional criteria versus new alternatives. Structural Equation Modeling, 6 (1): 1-55. DOI: 10.1080/10705519909540118

ICN (Instituto da Conservaçãoo da Natureza e da Bio-diversidade). 2005. URL: www.icn.pt.

ILHÉU, M. 2004. Padrões de uso de habitat da ictiofauna em rios de tipo mediterrânico. Ph.D. Thesis. Universidade de Évora, Évora, PortugaL.

ILHÉU, M., P. MATONO \& J. M. BERNARDO. 2014. Invasibility of mediterranean-climate rivers by non-native fish: The importance of environmental drivers and human pressures. PLoS ONE, 9(11). DOI: 10.1371/journal.pone. 0109694 
ILHÉU, M., P. MATONO, J. DA SILVA, C. SOUSA-SANTOS, D. VENADE, $M$. EMÍDIO, C. JINES, J. M. BERNARDO, A. M. COSTA, D. SOUSA, P. RODRIGUES, M. J. BARÃO, A. C. CARDOSO, C. CARRAPATO, H. LOUSA, N. SILVA, P. PINHEIRO, J. ALMEIDA, R. ALCAZAR. 2016. R. Ação A4 - Estudo sobre o impacte de alburno (Alburnus alburnus) sobre as populações de Saramugo. Relatório Final da Ação A4 do Projeto LIFE 13 NAT/PTT000786, Universidade de Évora.

KAKAREKO, T., J. KOBAK, J. GRABOWSKA, L. JERMACZ, M. PRZYBYLSKI, M, POZNANSKA, P. DARIUSZ \& G. H. COPP. 2013. Competitive interactions for food resources between invasive racer goby Babka gymnotrachelus and native European bullhead Cottus gobio. Biological Invasions, 15: 2519-2530. DOI: 10.1007/s10530-013-0470-7

KELLER, K. \& C. BROWN. 2008. Behavioural interactions between the introduced plague minnow Gambusia holbrooki and the vulnerable native Australian ornate rainbowfish Rhadinocentrus ornatus, under experimental conditions. Journal of Fish Biology, 73: 1714-1729. DOI: $10.1111 /$ j.1095-8649.2008.02045.x

KLINE, R. B. 2010. Principles and practice of structural equation modeling. Guilford Press, New York.

KRAUSE, J., R. K. BUTLIN, N. PEUHKURI \& V. L. PRITCHARD. 2000a. The social organization of fish shoals: a test of the predictive power of laboratory experiments for the field. Biological Reviews of the Cambridge Philosophical Society, 75: 477-501. DOI: 10.1111/j.1469-185X.2000.tb00052.x

KRAUSE, J., D. J. S. CHENG, E. KIRKMAN \& G. D. GROSSMAN. 2000b. Species-specific Patterns Of Refuge Use In Fish: The Role Of Metabolic Expenditure And Body Length. Behaviour, 137: 1113-1127. DOI: 10.1163/156853900502466

LANDEAU, L. \& J. TERBORGH. 1986. Oddity and the 'confusion effect' in predation. Animal Behaviour, 34: 1372-1380. DOI: 10.1016/S0003-3472(86)80208-1

LEGENDRE, P. \& L. LEGENDRE. 1998. Numerical Ecology, second edition. Elsevier, Amsterdam.
LEUNDA, P. M. 2010. Impacts of non-native fishes on Iberian freshwater ichthyofauna: Current knowledge and gaps. Aquatic Invasions, 5: 239-262. DOI: 10.3391/ai.2010.5.3.03

MacCALLUM, R. C. \& J. T. AUSTIN. 2000. Applications of structural equation modeling in psychological research. Annual Review of Psychology, 51: 201-226. DOI: 10.1146/annurev.psych.51.1.201

MASÓ, G., D. LATORRE, A. S. TARKAN, A. VILA-GISPERT \& D. ALMEIDA. 2016. Inter-population plasticity in growth and reproduction of invasive bleak, Alburnus alburnus (Cyprinidae, Actinopterygii), in northeastern Iberian Peninsula. Folia Zoologica, 65: 10-14. DOI: $10.25225 /$ fozo.v65.i1.a3.2016

McMANAMAY, R. A., B. K. PEOPLES, D. J. ORTH, C. A. DOLLOF \& D. C. OTURBAY, S., M. LOZADA \& V. CUSSAC. 2002. Aggressive behaviour between Gymnocharacinus bergi (Pisces, Characidae) and other Neotropical fishes from a thermal stream in Patagonia. Environmental Biology of Fishes, 63: 341-346. DOI: 10.1023/A: 1014388118188

PITCHER, T. 1979. Sensory information and the organization of behaviour in a shoaling cyprinid fish. Animal Behaviour, 27: 126-149. DOI: 10.1016/0003-3472(79)90133-7

PRITCHAR, V., J. LAWRENCE, R. K. BUTLIN \& J. KRAUSE. 2001. Shoal choice in zebrafish, Danio rerio: the influence of shoal size and activity. Animal Behaviour, 62: 1085-1088. DOI: 10.1006/anbe.2001.1858

RIBEIRO, F., I. G. COWX \& M. J. COLLARES-PEREIRA. 2000. Life history traits of the endangered Iberian cyprinid Anaecypris hispanica and their implications for conservation. Fundamental and Applied Limnology, 149(4): 569-586. DOI: 10.1127/archiv-hydrobiol/149/2000/569

RIBEIRO, F. \& P. M. LEUNDA. 2012. Non-native fish impacts on Mediterranean freshwater ecosystems: Current knowledge and research needs. Fisheries Management and Ecology, 19(2): 142-156. DOI: 10.1111/j.1365-2400. 2011.00842.X

RINCÓN, P. A., A. M. CORREAS, F. MORCILLO, P. RISUEÑO \& J- LOBÓN CERVIÁ. 
2002. Interaction between the introduced eastern mosquitofish and two autochthonous Spanish toothcarps. Journal of Fish Biology, 61: 1560-1585. DOI: $10.1111 / \mathrm{j} .1365-2400$. 2011.00842.x

SADOUL, B., P. EVOUNA MENGUES, N. C. FRIGGENS, P. PRUNET \& V. COLSON. 2014. A new method for measuring group behaviours of fish shoals from recorded videos taken in near aquaculture conditions. Aquaculture, 430: 179-187. DOI: 10.1016/j. aquaculture.2014.04.008

SAVERINO, C. \& R. GERLAI. 2009. The social zebrafish: Behavioral responses to conspecific, heterospecific, and computer animated fish. Behavioural Brain Research, 191: 77-87. DOI: 10.1016/j.bbr.2008.03.013.

SCHRECK, C. B., B. L. OLLA, M. W. DAIVS. 2011. Behavioral responses to stress. In: IWAMA GK, Pickering JP, Sumpter JP (eds), Fish Stress and Health in Aquaculture. Cambridge University Press, Cambridge, UK, pp 145-170.

SCHUMANN, D. A., W. W. HOBACK \& K. D. KOUPAL. 2015. Complex interactions between native and invasive species: investigating the differential displacement of two topminnows native to Nebraska. Aquatic Invasions, 10: 339-346. DOI: 10.3391/ai.2015.10.3.09

SHIPLEY, B. 2002. Cause and correlation in biology: a user's guide to path analysis, structural equations, and causal inference. Cambridge University Press, New York, USA.

SOUSA-SANTOS C., MATONO P., DA SILVA J., ILHÉU M. 2018. Evaluation of potential hybridazion between native fish and invasive bleak Alburnus alburnus. Acta Icthyologica et Piscatoria, 48(2): 109-122. DOI: 10.3750/ AIEP/02395

VAN KESSEL, N., M. DORENBOSCH, M. R. M. DE BOER, R. S. E. W. LEUVEN \& G. VAN DER VELDE. 2011. Competition for shelter between four invasive gobiids and two native benthic fish species. Current Zoology, 57 (6): 844-851. DOI: 10.1093/czoolo/57.6.844

VINYOLES, D., J. I. ROBALO, A. DE SOSTOA, A. ALMODÓVAR, B. ELVIRA, G. G. NICOLA, C. FERNÁNDEZ-DELGADO, C. S. SANTOS, I. DOADRIO, F. SARDÀ-PALOMERA \& F. ALMADA. 2007. Spread of the alien bleak Alburnus alburnus (Linnaeus, 1758) (Actinopterygii, Cyprinidae) in the Iberian Peninsula: the role of reservoirs. Graellsia, 63 (1): 101-110. http://hdl.handle.net/10400.12/1408

VINYOLES, D., M. PUIGCERVER \& J. D. RODRÍGUEZ-TEJEIRO. 2009. Interacciones comportamentales entre un pez autóctono (Parachondrostoma miegii) y un invasor (Alburnus alburnus) en condiciones experimentales. III Congreso Nacional sobre Especies Exóticas Invasoras. 24-27 November, 2009. Zaragoza, Spain.

WARD, A. J. W., S. AXFORD \& J. KRAUSE. 2002. Mixed-species shoaling in fish: The sensory mechanisms and costs of shoal choice. Behavioral Ecology and Sociobiology, 52: 182-187. DOI: $10.1007 / \mathrm{s} 00265-002-0505-\mathrm{z}$

WONG, B. B. M., \& U. CANDOLIN. 2015. Behavioral responses to changing environments. Behavioral Ecology, 26 (3): 665-673. DOI: 10.1093/beheco/aru183

Con el apoyo de:
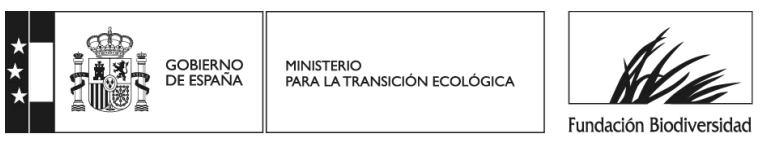